\title{
Biomarker Levels in Patients with Atrial Fibrillation Before and After Electrical Cardioversion
}

\author{
Pascal B Meyre ( $\square$ pascal.meyre@usb.ch ) \\ University Hospital Basel \\ Stefanie Aeschbacher \\ University Hospital Basel \\ Steffen Blum \\ University Hospital Basel \\ Gian Voellmin \\ University Hospital Basel \\ Peter M Kastner \\ Roche Diagnostics GmbH \\ Elisa Hennings \\ University Hospital Basel \\ Beat A Kaufmann \\ University Hospital Basel \\ Michael Kühne \\ University Hospital Basel \\ Stefan Osswald \\ University Hospital Basel \\ David Conen \\ University Hospital Basel
}

\section{Research Article}

Keywords: Biomarkers, atrial fibrillation, cardioversion, recurrence, BMP10, NT-proBNP

Posted Date: November 18th, 2021

DOl: https://doi.org/10.21203/rs.3.rs-1054237/v1

License: (c) (i) This work is licensed under a Creative Commons Attribution 4.0 International License. Read Full License 


\section{Abstract \\ Background}

Biomarkers may help to improve our knowledge about the complex pathophysiology of atrial fibrillation (AF), the most common sustained cardiac arrhythmia. We aimed to identify significant changes in biomarkers and clinical measures in patients with and without AF recurrence after electrical cardioversion.

\section{Methods}

Patients with persistent AF undergoing elective electrical cardioversion were enrolled. We measured 21 conventional and new biomarkers before and 30 days after electrical cardioversion and assessed the associations of changes in biomarker levels with rhythm status at follow-up using multivariable logistic regression models.

\section{Results}

Of the 100 patients included (mean [SD] age 66 (10) years, 25\% women), 28 (28\%) had an AF recurrence. Of the 21 biomarkers assessed, 4 reached the predefined between group significance of $p<0.01$. The most significant ones were bone morphogenetic protein 10 (BMP10), N-terminal pro-B-type natriuretic peptide (NT-proBNP) and total bilirubin. Their respective changes were $-10.4 \%,-62.0 \%$ and $-25.6 \%$ in patients with sinus rhythm, and $3.1 \%, 1.1 \%$ and $-9.4 \%$ in patients with recurrent $A F$, for a between group difference of $-13.5 \%$ (95\% confidence interval [Cl], $-19.3 \%$ to $-7.6 \% ; \mathrm{P}<0.001),-63.1 \%(95 \% \mathrm{Cl},-76.6 \%$ to $-49.6 \% ; \mathrm{P}<0.001$ ) and -16.3 (95\% $\mathrm{Cl},-27.9 \%$ to $-4.7 \%$; $\mathrm{P}=0.007)$. In age and sex adjusted models, reductions of BMP10 and NT-proBNP were significantly associated with rhythm status at follow-up ( $\beta$ coefficient per 1-SD decrease, $-2.03 ; 95 \% \mathrm{Cl},-3.06$ to $-1.00 ; \mathrm{P}<0.001$ and $-3.98 ; 95 \% \mathrm{Cl},-5.75$ to $-2.22 ; \mathrm{P}<0.001$, respectively). After additional adjustment for demographic characteristics, risk factors for $A F$, and changes in clinical measures, the $\beta$ coefficients per 1-SD were $-3.85(95 \% \mathrm{Cl},-6.34$ to $-1.35 ; P=0.003)$ for $B M P 10$ and $-5.84(95 \% \mathrm{Cl},-10.22$ to $-1.47 ; \mathrm{P}=0.009)$ for NT-proBNP.

\section{Conclusions}

Changes in BMP10 und NT-proBNP levels were strongly associated with rhythm status after electrical cardioversion, suggesting that these markers may be dependent on the actual heart rhythm.

\section{Introduction}

Although extensive epidemiological and experimental research has been conducted to identify risk factors for atrial fibrillation (AF), current knowledge about the complex AF pathophysiology remains incomplete. While data from previous studies suggest that several biomarkers of inflammation (C-reactive protein and fibrinogen) ${ }^{1}$, myocardial injury (high-sensitivity troponin I) ${ }^{2}$, renal dysfunction (fibroblast growth factor-23) ${ }^{3}$, and hemodynamic stress (NT-proBNP [N-terminal pro-B-type natriuretic peptide] $)^{4-6}$ are independently associated with prevalent and incident $A F$, other biomarkers may also be important. In one observational study, elevated levels of bone morphogenetic protein 10 (BMP10), a recently discovered atrial-restricted protein, measured at baseline were associated with an increased risk of AF recurrence among patients who underwent catheter ablation for $\mathrm{AF}^{7}$. Identification of novel biomarkers associated with AF may help to advance our knowledge of AF. Additionally, these biomarkers may eventually improve established AF screening strategies.

However, the observed relationships may at least in part be explained through well-established associations between biomarkers and cardiovascular conditions related to AF, as residual confounding is a potential issue for studies looking at between-group differences over a relatively long follow-up period. Within-person changes during short-term follow-up may 
therefore provide a more precise and unbiased picture of the associations between biomarker levels and rhythm status.

Patients undergoing elective electrical cardioversion provide an ideal experimental framework for this purpose.

The Gene Expression Patterns for the Prediction of Atrial Fibrillation (GAPP-AF) study measured 11 conventional and new biomarkers and performed laboratory measures in AF patients before and after electrical cardioversion. The aim of this study was to assess the association of changes in biomarkers with changes in heart rhythm status among patients with persistent AF undergoing elective electrical cardioversion.

\section{Results}

\section{Baseline characteristics}

Baseline characteristics stratified by rhythm status at follow-up are presented in Table 1. During follow-up, 28 (28\%) patients had a documented AF recurrence. There were no statistically significant between-group differences. 
Table 1

Baseline characteristics of patients with and without AF recurrence after cardioversion

\begin{tabular}{|c|c|c|c|c|}
\hline Characteristic & $\begin{array}{l}\text { All patients } \\
(\mathrm{N}=100)\end{array}$ & $\begin{array}{l}\text { Patients with } \\
\text { AF recurrence } \\
(\mathrm{N}=28)\end{array}$ & $\begin{array}{l}\text { Patients in } \\
\text { sinus rhythm } \\
(\mathrm{N}=72)\end{array}$ & $P$ value \\
\hline Age, years & $66 \pm 10$ & $67 \pm 8$ & $66 \pm 11$ & 0.61 \\
\hline Sex, No. (\%) & & & & 0.44 \\
\hline Women & $25(25)$ & $5(18)$ & $20(28)$ & \\
\hline Men & $75(75)$ & $23(82)$ & $52(72)$ & \\
\hline Body-mass index, median (IQR), $\mathrm{kg} / \mathrm{m}^{2}$ & $26.0(24.2-29.5)$ & $25.7(22.9-29.5)$ & $27.0(24.4-29.5)$ & 0.63 \\
\hline Smoking status, No. (\%) & & & & 0.07 \\
\hline Active & $11(11)$ & $2(7)$ & $9(12)$ & \\
\hline Past & $49(49)$ & $19(68)$ & $30(42)$ & \\
\hline Never & $40(40)$ & $7(25)$ & $33(46)$ & \\
\hline $\begin{array}{l}\text { Months since atrial fibrillation diagnosis, } \\
\text { median (IQR) }\end{array}$ & $16(4-76)$ & $9(4-47)$ & $19(4-79)$ & 0.31 \\
\hline \multicolumn{5}{|l|}{ Medical history, No. (\%) } \\
\hline Hypertension & $64(64)$ & $21(75)$ & $43(60)$ & 0.17 \\
\hline Diabetes mellitus & $6(6)$ & $2(7)$ & $4(6)$ & 0.67 \\
\hline Stroke or transient ischemic attack & $11(11)$ & $2(7)$ & $9(13)$ & 0.72 \\
\hline Myocardial infarction & $8(8)$ & $2(7)$ & $6(8)$ & 0.99 \\
\hline Percutaneous coronary intervention & $12(12)$ & $3(11)$ & $9(13)$ & 0.99 \\
\hline Heart failure & $14(14)$ & $5(18)$ & $9(13)$ & 0.53 \\
\hline \multicolumn{5}{|l|}{ Medication, No. (\%) } \\
\hline Beta-blocker & $76(76)$ & $18(64)$ & $58(82)$ & 0.11 \\
\hline Calcium channel blockers & $15(15)$ & $5(18)$ & $10(14)$ & 0.76 \\
\hline Flecainide & $4(4)$ & $1(4)$ & $3(4)$ & 0.99 \\
\hline Amiodarone & $41(41)$ & $10(36)$ & $31(44)$ & 0.51 \\
\hline Dronedarone & $7(7)$ & $3(11)$ & $4(6)$ & 0.40 \\
\hline Digoxin or digitoxin & $8(8)$ & $3(11)$ & $5(7)$ & 0.68 \\
\hline
\end{tabular}

\section{Changes in biomarkers by rhythm status at follow-up}

Absolute values of biomarker levels and clinical measures at baseline and follow-up are presented in Table 2 and S1 Table. Differences in biomarker levels according to rhythm status at follow-up are shown in Table 3 and (Fig. 1). Between-group differences exceeding the threshold of $p<0.01$ were observed for BMP10, NT-proBNP, total NT-proBNP and total bilirubin. 
Waterfall plots of individual percent change in biomarker levels are presented in (Fig. 2). There were significant correlations between levels of BMP10, NT-proBNP, total NT-proBNP, and BNP at baseline and follow-up, but not for total bilirubin, as shown in S2 and S3 Tables, and S2 and S3 Figs. 
Absolute biomarker levels at baseline and follow-up stratified by rhythm status at follow-up

\begin{tabular}{|c|c|c|c|c|c|c|}
\hline & Baseline & & & Follow-up & & \\
\hline Biomarkers & AF recurrence & Sinus rhythm & $\begin{array}{l}P \\
\text { value }\end{array}$ & AF recurrence & Sinus rhythm & $\begin{array}{l}P \\
\text { value }\end{array}$ \\
\hline FABP3, ng/mL & $37.26 \pm 11.36$ & $37.82 \pm 15.63$ & 0.43 & $34.74 \pm 12.91$ & $34.08 \pm 14.04$ & 0.68 \\
\hline ESM1, ng/mL & $2.39 \pm 0.82$ & $2.44 \pm 0.98$ & 0.99 & $2.34 \pm 0.74$ & $2.15 \pm 0.68$ & 0.13 \\
\hline BMP10, ng/mL & $2.38 \pm 0.56$ & $2.40 \pm 0.72$ & 0.79 & $2.46 \pm 0.65$ & $2.09 \pm 0.48$ & 0.0076 \\
\hline $\mathrm{DKK} 3, \mathrm{ng} / \mathrm{mL}$ & $62.67 \pm 18.71$ & $62.82 \pm 16.87$ & 0.84 & $64.16 \pm 21.21$ & $59.91 \pm 16.92$ & 0.50 \\
\hline $\mathrm{FGF} 23, \mathrm{ng} / \mathrm{mL}$ & $268.27 \pm 259.71$ & $338.05 \pm 726.94$ & 0.13 & $267.50 \pm 215.78$ & $244.68 \pm 469.87$ & 0.0363 \\
\hline IGFBP7, ng/mL & $108.77 \pm 34.87$ & $103.17 \pm 25.75$ & 0.67 & $110.71 \pm 28.98$ & $101.30 \pm 22.72$ & 0.16 \\
\hline MyBPC3, ng/L & $19.15 \pm 13.50$ & $21.61 \pm 34.44$ & 0.45 & $23.01 \pm 19.18$ & $21.71 \pm 22.33$ & 0.57 \\
\hline $\begin{array}{l}\text { NT-proBNP, } \\
\mathrm{pg} / \mathrm{mL}\end{array}$ & $1167.39 \pm 690.88$ & $1311.35 \pm 1156.85$ & 0.99 & $1165.03 \pm 887.36$ & $512.82 \pm 522.43$ & $<0.001$ \\
\hline $\begin{array}{l}\text { total NT-proBNP, } \\
\mathrm{pg} / \mathrm{mL}\end{array}$ & $3672.49 \pm 2668.65$ & $3822.49 \pm 2916.65$ & 0.99 & $3702.79 \pm 2765.81$ & $2455.07 \pm 1931.88$ & 0.0200 \\
\hline BNP, pg/mL & $488.71 \pm 751.64$ & $336.60 \pm 265.16$ & 0.99 & $302.76 \pm 195.05$ & $224.25 \pm 203.08$ & 0.0147 \\
\hline hsTnT, pg/mL & $13.78 \pm 11.45$ & $11.97 \pm 11.05$ & 0.39 & $15.67 \pm 12.97$ & $11.69 \pm 9.69$ & 0.16 \\
\hline Sodium, mmol/L & $140.52 \pm 2.36$ & $140.68 \pm 2.03$ & 0.80 & $141.13 \pm 2.47$ & $140.96 \pm 2.21$ & 0.81 \\
\hline $\begin{array}{l}\text { Potassium, } \\
\mathrm{mmol} / \mathrm{L}\end{array}$ & $4.18 \pm 0.40$ & $4.11 \pm 0.46$ & 0.24 & $4.23 \pm 0.29$ & $4.16 \pm 0.43$ & 0.46 \\
\hline $\begin{array}{l}\text { Creatinine, } \\
\text { umol/L }\end{array}$ & $89.69 \pm 27.03$ & $87.09 \pm 22.28$ & 0.98 & $91.42 \pm 28.68$ & $89.12 \pm 31.14$ & 0.89 \\
\hline Urea, mmol/L & $7.27 \pm 3.01$ & $6.77 \pm 2.42$ & 0.65 & $7.16 \pm 1.90$ & $7.51 \pm 3.69$ & 0.99 \\
\hline $\begin{array}{l}\text { Total bilirubin, } \\
\text { umol/L }\end{array}$ & $11.88 \pm 6.12$ & $13.46 \pm 5.39$ & 0.11 & $10.50 \pm 6.52$ & $9.62 \pm 4.25$ & 0.86 \\
\hline $\begin{array}{l}\text { Aspartate } \\
\text { aminotransferase, } \\
\text { U/L }\end{array}$ & $30.46 \pm 8.66$ & $31.32 \pm 9.66$ & 0.79 & $32.13 \pm 10.17$ & $31.86 \pm 9.37$ & 0.86 \\
\hline $\begin{array}{l}\text { Alanine } \\
\text { aminotransferase, } \\
\text { U/L }\end{array}$ & $29.75 \pm 15.62$ & $34.25 \pm 16.70$ & 0.18 & $28.25 \pm 13.01$ & $33.25 \pm 16.25$ & 0.25 \\
\hline $\begin{array}{l}\text { C-reactive protein, } \\
\mathrm{mg} / \mathrm{L}\end{array}$ & $2.11 \pm 2.85$ & $4.14 \pm 8.91$ & 0.24 & $2.64 \pm 4.11$ & $2.95 \pm 3.55$ & 0.38 \\
\hline $\begin{array}{l}\text { Lactate } \\
\text { dehydrogenase, } \\
\text { U/L }\end{array}$ & $230.87 \pm 63.95$ & $226.43 \pm 64.28$ & 0.73 & $246.46 \pm 67.84$ & $218.86 \pm 51.49$ & 0.14 \\
\hline $\begin{array}{l}\text { Creatine kinase, } \\
\text { U/L }\end{array}$ & $140.96 \pm 89.65$ & $109.56 \pm 94.38$ & 0.0115 & $134.71 \pm 68.23$ & $131.40 \pm 95.38$ & 0.32 \\
\hline
\end{tabular}


Abbreviations: FABP3, fatty acid binding protein 3; ESM1, endothelial cell-specific molecule-1; BMP10, bone morphogenetic protein 10; DKK3; dickkopf-3; FGF23, fibroblast growth factor 23; IGFBP7, insulin growth factor binding protein-7; MyBPC3, myosin-binding protein C; NT-proBNP, N-terminal pro-B-type natriuretic peptide; BNP, brain natriuretic peptide; hsTnT, highsensitive troponin T.

Values are mean \pm standard deviation.

$\mathrm{P}$ value compares biomarkers levels between patient with AF recurrence and patients with sinus rhythm and are calculated using Wilcoxon rank-sum test. 
Table 3

Changes in biomarker concentrations by rhythm status at follow-up

\begin{tabular}{|c|c|c|c|c|c|c|c|}
\hline \multirow[b]{2}{*}{ Biomarkers } & \multicolumn{3}{|c|}{ Absolute change in markers $(95 \% \mathrm{Cl})^{a}$} & \multicolumn{4}{|c|}{ Percent change in markers $(95 \% \mathrm{Cl})$} \\
\hline & $\begin{array}{l}\text { AF } \\
\text { recurrence }\end{array}$ & $\begin{array}{l}\text { Sinus } \\
\text { rhythm }\end{array}$ & $\begin{array}{l}\text { Between-Group } \\
\text { Difference }\end{array}$ & $\begin{array}{l}\text { AF } \\
\text { recurrence }\end{array}$ & $\begin{array}{l}\text { Sinus } \\
\text { rhythm }\end{array}$ & $\begin{array}{l}\text { Between-Group } \\
\text { Difference }\end{array}$ & $\begin{array}{l}P \\
\text { value }\end{array}$ \\
\hline \multirow[t]{2}{*}{$\mathrm{FABP} 3, \mathrm{ng} / \mathrm{mL}$} & -2.34 & -3.75 & -1.41 & -5.95 & -8.43 & -2.48 & 0.45 \\
\hline & $\begin{array}{l}(-5.52 \text { to } \\
0.84)\end{array}$ & $\begin{array}{l}(-5.71 \text { to } \\
-1.80)\end{array}$ & $(-5.10$ to 2.28$)$ & $\begin{array}{l}(-14.33 \text { to } \\
2.43)\end{array}$ & $\begin{array}{l}(-12.54 \text { to } \\
-4.31)\end{array}$ & $(-10.79$ to 5.84$)$ & \\
\hline \multirow[t]{2}{*}{ ESM1, ng/mL } & -0.03 & -0.29 & 0.26 & 0.59 & -8.13 & -8.73 & 0.07 \\
\hline & $\begin{array}{l}(-0.19 \text { to } \\
0.12)\end{array}$ & $\begin{array}{l}(-0.45 \text { to } \\
-0.13)\end{array}$ & $(-0.54$ to 0.03$)$ & $\begin{array}{l}(-6.05 \text { to } \\
7.24)\end{array}$ & $\begin{array}{l}(-12.29 \text { to } \\
-3.98)\end{array}$ & $\begin{array}{l}(-16.54 \text { to } \\
-0.91)\end{array}$ & \\
\hline \multirow[t]{2}{*}{ BMP10, ng/mL } & 0.07 & -0.31 & -0.38 & 3.07 & -10.40 & -13.47 & $<0.001$ \\
\hline & $\begin{array}{l}(-0.03 \text { to } \\
0.19)\end{array}$ & $\begin{array}{l}(-0.42 \text { to } \\
-0.19)\end{array}$ & $(-0.57$ to -0.19$)$ & $\begin{array}{l}(-0.78 \text { to } \\
6.92)\end{array}$ & $\begin{array}{l}(-13.70 \text { to } \\
-7.10)\end{array}$ & $\begin{array}{l}(-19.31 \text { to } \\
-7.63)\end{array}$ & \\
\hline \multirow[t]{2}{*}{$\mathrm{DKK} 3, \mathrm{ng} / \mathrm{mL}$} & 1.69 & -2.91 & -4.61 & 3.02 & -3.74 & -6.76 & 0.0216 \\
\hline & $\begin{array}{l}(-1.80 \text { to } \\
5.18)\end{array}$ & $\begin{array}{l}(-4.97 \text { to } \\
-0.86)\end{array}$ & $(-8.52$ to -0.69$)$ & $\begin{array}{l}(-2.06 \text { to } \\
8.09)\end{array}$ & $\begin{array}{l}(-7.19 \text { to } \\
-0.29)\end{array}$ & $\begin{array}{l}(-13.10 \text { to } \\
-0.41)\end{array}$ & \\
\hline \multirow[t]{2}{*}{ FGF23, ng/mL } & -1.43 & -93.38 & -91.95 & 6.34 & -7.12 & -13.45 & 0.42 \\
\hline & $\begin{array}{l}(-37.92 \text { to } \\
35.06)\end{array}$ & $\begin{array}{l}(-232.31 \text { to } \\
45.55)\end{array}$ & $\begin{array}{l}(-319.50 \text { to } \\
135.61)\end{array}$ & $\begin{array}{l}(-6.23 \text { to } \\
18.90)\end{array}$ & $\begin{array}{l}(-13.84 \text { to } \\
-0.39)\end{array}$ & $\begin{array}{l}(-26.66 \text { to } \\
-0.24)\end{array}$ & \\
\hline \multirow[t]{2}{*}{ IGFBP7, ng/mL } & 2.04 & -1.88 & -3.91 & 3.31 & -0.42 & -3.73 & 0.24 \\
\hline & $\begin{array}{l}(-3.32 \text { to } \\
7.39)\end{array}$ & $\begin{array}{l}(-5.45 \text { to } \\
1.70)\end{array}$ & $(-10.53$ to 2.71$)$ & $\begin{array}{l}(-0.36 \text { to } \\
6.99)\end{array}$ & $\begin{array}{l}(-3.47 \text { to } \\
2.64)\end{array}$ & $(-9.16$ to 1.70$)$ & \\
\hline \multirow[t]{2}{*}{ MyBPC3, ng/L } & 4.13 & 0.31 & -3.80 & 24.31 & 20.02 & -4.30 & 0.41 \\
\hline & $\begin{array}{l}(-0.44 \text { to } \\
8.70)\end{array}$ & $\begin{array}{l}(-5.04 \text { to } \\
5.70)\end{array}$ & $(-12.91$ to 5.30$)$ & $\begin{array}{l}(1.19 \text { to } \\
47.44)\end{array}$ & $\begin{array}{l}(11.20 \text { to } \\
28.83)\end{array}$ & $\begin{array}{l}(-24.05 \text { to } \\
15.45)\end{array}$ & \\
\hline \multirow[t]{2}{*}{ NT-proBNP, pg/mL } & 5.1 & -798.5 & -803.6 & 1.09 & -62.02 & -63.11 & $<0.001$ \\
\hline & $\begin{array}{l}(-196.8 \text { to } \\
207.0)\end{array}$ & $\begin{array}{l}(-986.4 \text { to } \\
-610.7)\end{array}$ & $\begin{array}{l}(-1132.0 \text { to } \\
-475.2)\end{array}$ & $\begin{array}{l}(-16.18 \text { to } \\
18.35)\end{array}$ & $\begin{array}{l}(-67.54 \text { to } \\
-56.50)\end{array}$ & $\begin{array}{l}(-76.64 \text { to } \\
-49.57)\end{array}$ & \\
\hline \multirow{2}{*}{$\begin{array}{l}\text { total NT-proBNP, } \\
\mathrm{pg} / \mathrm{mL}\end{array}$} & -7.8 & -1367.4 & -1375.2 & 2.66 & -33.35 & -36.01 & 0.001 \\
\hline & $\begin{array}{l}(-514.5 \text { to } \\
530.1)\end{array}$ & $\begin{array}{l}(-1821.2 \text { to } \\
-913.6)\end{array}$ & $\begin{array}{l}(-2176.0 \text { to } \\
-574.4)\end{array}$ & $\begin{array}{l}(-11.15 \text { to } \\
16.46)\end{array}$ & $\begin{array}{l}(-42.52 \text { to } \\
-24.19)\end{array}$ & $\begin{array}{l}(-53.01 \text { to } \\
-19.01)\end{array}$ & \\
\hline \multirow[t]{2}{*}{ BNP, pg/mL } & -19.40 & -120.98 & -101.58 & 10.70 & -30.65 & -41.34 & 0.0433 \\
\hline & $\begin{array}{l}(-110.31 \text { to } \\
71.52)\end{array}$ & $\begin{array}{l}(-171.02 \text { to } \\
-70.93)\end{array}$ & $\begin{array}{l}(-200.03 \text { to } \\
-3.14)\end{array}$ & $\begin{array}{l}(-6.99 \text { to } \\
28.38)\end{array}$ & $\begin{array}{l}(-43.65 \text { to } \\
-17.65)\end{array}$ & $\begin{array}{l}(-65.35 \text { to } \\
-17.34)\end{array}$ & \\
\hline \multirow[t]{2}{*}{ hsTnT, pg/mL } & 1.50 & -0.32 & -1.81 & 6.87 & 5.16 & -1.71 & 0.11 \\
\hline & $\begin{array}{l}(0.14 \text { to } \\
2.85)\end{array}$ & $\begin{array}{l}(-1.71 \text { to } \\
1.08)\end{array}$ & $(-4.21$ to 0.58$)$ & $\begin{array}{l}(-10.98 \text { to } \\
24.71)\end{array}$ & $\begin{array}{l}(-6.66 \text { to } \\
16.97)\end{array}$ & $\begin{array}{l}(-23.56 \text { to } \\
20.13)\end{array}$ & \\
\hline \multirow[t]{2}{*}{ Sodium, $\mathrm{mmol} / \mathrm{L}$} & 0.33 & 0.16 & -0.17 & 0.26 & 0.13 & -0.12 & 0.79 \\
\hline & $\begin{array}{l}(-0.87 \text { to } \\
1.54)\end{array}$ & $\begin{array}{l}(-0.46 \text { to } \\
0.79)\end{array}$ & $(-1.41$ to 1.07$)$ & $\begin{array}{l}(-0.60 \text { to } \\
1.11)\end{array}$ & $\begin{array}{l}(-0.31 \text { to } \\
0.58)\end{array}$ & $(-1.01$ to 0.76$)$ & \\
\hline
\end{tabular}




\begin{tabular}{|c|c|c|c|c|c|c|c|}
\hline \multirow[b]{2}{*}{ Potassium, mmol/L } & \multicolumn{3}{|c|}{ Absolute change in markers $(95 \% \mathrm{Cl})^{a}$} & \multicolumn{4}{|c|}{ Percent change in markers $(95 \% \mathrm{Cl})$} \\
\hline & 0.05 & 0.05 & 0.008 & 1.69 & 1.82 & 0.14 & 0.93 \\
\hline & $\begin{array}{l}(-0.10 \text { to } \\
0.19)\end{array}$ & $\begin{array}{l}(-0.04 \text { to } \\
0.15)\end{array}$ & $(-0.17$ to 0.18$)$ & $\begin{array}{l}(-1.92 \text { to } \\
5.30)\end{array}$ & $\begin{array}{l}(-0.40 \text { to } \\
4.05)\end{array}$ & $(-4.10$ to 4.38$)$ & \\
\hline \multirow[t]{2}{*}{ Creatinine, umol/L } & 1.39 & -0.09 & -1.48 & 1.58 & -0.32 & -1.90 & 0.69 \\
\hline & $\begin{array}{l}(-2.43 \text { to } \\
5.22)\end{array}$ & $\begin{array}{l}(-4.32 \text { to } \\
4.14)\end{array}$ & $(-8.91$ to 5.94$)$ & $\begin{array}{l}(-2.41 \text { to } \\
5.57)\end{array}$ & $\begin{array}{l}(-4.29 \text { to } \\
3.64)\end{array}$ & $(-8.93$ to 5.12$)$ & \\
\hline \multirow[t]{2}{*}{ Urea, $\mathrm{mmol} / \mathrm{L}$} & -0.13 & 0.65 & 0.79 & 3.02 & 9.95 & 6.62 & 0.10 \\
\hline & $\begin{array}{l}(-0.85 \text { to } \\
0.58)\end{array}$ & $\begin{array}{l}(0.14 \text { to } \\
1.17)\end{array}$ & $(-0.17$ to 1.74$)$ & $\begin{array}{l}(-4.73 \text { to } \\
10.76)\end{array}$ & $\begin{array}{l}\text { (3.75 to } \\
15.52)\end{array}$ & $(-4.13$ to 17.37$)$ & \\
\hline \multirow{2}{*}{$\begin{array}{l}\text { Total bilirubin, } \\
\text { umol/L }\end{array}$} & -1.39 & -3.75 & -2.35 & -9.35 & -25.64 & -16.29 & 0.0065 \\
\hline & $\begin{array}{l}(-3.03 \text { to } \\
0.25)\end{array}$ & $\begin{array}{l}(-4.59 \text { to } \\
-2.91)\end{array}$ & $(-4.03$ to -0.68$)$ & $\begin{array}{l}(-21.14 \text { to } \\
2.44)\end{array}$ & $\begin{array}{l}(-31.37 \text { to } \\
-19.91)\end{array}$ & $\begin{array}{l}(-27.92 \text { to } \\
-4.66)\end{array}$ & \\
\hline \multirow{2}{*}{$\begin{array}{l}\text { Aspartate } \\
\text { aminotransferase, } \\
\mathrm{U} / \mathrm{L}\end{array}$} & 2.13 & 0.76 & -1.37 & 7.06 & 5.91 & -1.15 & 0.42 \\
\hline & $\begin{array}{l}(0.45 \text { to } \\
3.81)\end{array}$ & $\begin{array}{l}(-1.18 \text { to } \\
2.70)\end{array}$ & $(-4.72$ to 1.98$)$ & $\begin{array}{l}(1.53 \text { to } \\
12.59)\end{array}$ & $\begin{array}{l}(-0.28 \text { to } \\
12.09)\end{array}$ & $(-11.86$ to 9.55$)$ & \\
\hline \multirow{2}{*}{$\begin{array}{l}\text { Alanine } \\
\text { aminotransferase, } \\
\mathrm{U} / \mathrm{L}\end{array}$} & 0.30 & -0.84 & -1.15 & 3.70 & 8.24 & 4.55 & 0.73 \\
\hline & $\begin{array}{l}(-2.13 \text { to } \\
2.74)\end{array}$ & $\begin{array}{l}(-4.81 \text { to } \\
3.13)\end{array}$ & $(-7.86$ to 5.57$)$ & $\begin{array}{l}(-7.40 \text { to } \\
14.80)\end{array}$ & $\begin{array}{l}(-5.06 \text { to } \\
21.55)\end{array}$ & $\begin{array}{l}(-18.35 \text { to } \\
27.44)\end{array}$ & \\
\hline \multirow{2}{*}{$\begin{array}{l}\text { C-reactive protein, } \\
\mathrm{mg} / \mathrm{L}\end{array}$} & 0.37 & -1.26 & -1.63 & 20.23 & 25.97 & 5.74 & 0.34 \\
\hline & $\begin{array}{l}(-1.15 \text { to } \\
1.89)\end{array}$ & $\begin{array}{l}(-3.26 \text { to } \\
0.73)\end{array}$ & $(-5.05$ to 1.78$)$ & $\begin{array}{l}(-7.28 \text { to } \\
47.73)\end{array}$ & $\begin{array}{l}(0.44 \text { to } \\
51.50)\end{array}$ & $\begin{array}{l}(-39.29 \text { to } \\
50.78)\end{array}$ & \\
\hline \multirow{2}{*}{$\begin{array}{l}\text { Lactate } \\
\text { dehydrogenase, U/L }\end{array}$} & 17.26 & -9.63 & -26.90 & 8.39 & -1.53 & -9.92 & 0.0267 \\
\hline & $\begin{array}{l}(0.83 \text { to } \\
33.69)\end{array}$ & $\begin{array}{l}(-22.80 \text { to } \\
3.53)\end{array}$ & $\begin{array}{l}(-50.61 \text { to } \\
-3.18)\end{array}$ & $\begin{array}{l}(1.41 \text { to } \\
15.36)\end{array}$ & $\begin{array}{l}(-6.00 \text { to } \\
2.93)\end{array}$ & $\begin{array}{l}(-18.31 \text { to } \\
-1.52)\end{array}$ & \\
\hline \multirow[t]{2}{*}{ Creatine kinase, $\mathrm{U} / \mathrm{L}$} & -4.39 & 19.11 & 23.50 & 3.19 & 21.92 & 18.73 & 0.0465 \\
\hline & $\begin{array}{l}(-22.16 \text { to } \\
13.38)\end{array}$ & $\begin{array}{l}(6.63 \text { to } \\
31.59)\end{array}$ & $(0.38$ to 46.62$)$ & $\begin{array}{l}(-10.01 \text { to } \\
16.39)\end{array}$ & $\begin{array}{l}(11.01 \text { to } \\
32.83)\end{array}$ & $(-0.93$ to 38.39$)$ & \\
\hline \multicolumn{8}{|c|}{$\begin{array}{l}\text { Abbreviations: FABP3, fatty acid binding protein 3; ESM1, endothelial cell-specific molecule-1; BMP10, bone morphogenetic } \\
\text { protein 10; DKK3; dickkopf related protein-3; FGF23, fibroblast growth factor 23; IGFBP7, insulin growth factor binding } \\
\text { protein-7; MyBPC3, myosin-binding protein C; NT-proBNP, N-terminal pro-B-type natriuretic peptide; BNP, brain natriuretic } \\
\text { peptide; hsTnT, high-sensitive troponin T. }\end{array}$} \\
\hline \multicolumn{8}{|c|}{ a mean difference with corresponding $95 \%$ confidence intervals. } \\
\hline \multicolumn{8}{|c|}{$\begin{array}{l}\mathrm{P} \text { value compares mean differences of biomarkers between patient with AF recurrence and patients with sinus rhythm and } \\
\text { are calculated using 2-sample t tests. }\end{array}$} \\
\hline
\end{tabular}

\section{Changes in clinical measures by rhythm status at follow-up}

Changes in clinical measures are presented in Table 4. We observed significant between group differences in average and maximum heart rate (between-group difference, $-17.3 \% ; 95 \% \mathrm{Cl},-30.0$ to -4.6 and $-29.2 \% ; 95 \% \mathrm{Cl},-41.2$ to -17.3 , respectively). Because NT-proBNP and total NT-proBNP were highly correlated (Spearman's rho at baseline and follow-up, 0.9364 and 0.918 [S2 and S3 Tables]), we used only NT-proBNP for further investigation given its routine availability in clinical practice. 


\begin{tabular}{|c|c|c|c|c|c|c|c|}
\hline & \multicolumn{3}{|c|}{ Absolute change in markers $(95 \% \mathrm{Cl})^{a}$} & \multicolumn{4}{|c|}{ Percent change in markers $(95 \% \mathrm{Cl})$} \\
\hline & $\begin{array}{l}\mathrm{AF} \\
\text { recurrence }\end{array}$ & $\begin{array}{l}\text { Sinus } \\
\text { rhythm }\end{array}$ & $\begin{array}{l}\text { Between-Group } \\
\text { Difference }\end{array}$ & $\begin{array}{l}\text { AF } \\
\text { recurrence }\end{array}$ & $\begin{array}{l}\text { Sinus } \\
\text { rhythm }\end{array}$ & $\begin{array}{l}\text { Between-Group } \\
\text { Difference }\end{array}$ & $\begin{array}{l}P \\
\text { value }\end{array}$ \\
\hline \multicolumn{8}{|l|}{$\begin{array}{l}\text { Blood pressure } \\
\text { measures }\end{array}$} \\
\hline \multirow[t]{2}{*}{ Systolic, mmHg } & -5.17 & -1.49 & 3.68 & -2.96 & -0.53 & 2.43 & 0.38 \\
\hline & $\begin{array}{l}(-13.14 \text { to } \\
2.79)\end{array}$ & $\begin{array}{l}(-5.66 \text { to } \\
2.68)\end{array}$ & $(-4.66$ to 12.02$)$ & $\begin{array}{l}(-8.14 \text { to } \\
2.22)\end{array}$ & $\begin{array}{l}(-3.47 \text { to } \\
2.40)\end{array}$ & $(-3.32$ to 8.18$)$ & \\
\hline \multirow{2}{*}{$\begin{array}{l}\text { Diastolic, } \\
\mathrm{mmHg}\end{array}$} & -1.85 & -9.29 & -7.44 & -1.20 & -9.30 & -8.10 & 0.0181 \\
\hline & $\begin{array}{l}(-7.43 \text { to } \\
3.73)\end{array}$ & $\begin{array}{l}(-12.41 \text { to } \\
-6.16)\end{array}$ & $(-13.58$ to -1.30$)$ & $\begin{array}{l}(-6.95 \text { to } \\
4.55)\end{array}$ & $\begin{array}{l}(-12.75 \text { to } \\
-5.85)\end{array}$ & $(-14.77$ to -1.44$)$ & \\
\hline \multicolumn{8}{|l|}{$\begin{array}{l}\text { Holter ECG } \\
\text { parameters }\end{array}$} \\
\hline \multirow{2}{*}{$\begin{array}{l}\text { Average heart } \\
\text { rate, /min }\end{array}$} & -6.50 & -22.13 & -15.63 & -6.57 & -23.89 & -17.31 & 0.0011 \\
\hline & $\begin{array}{l}(-16.22 \text { to } \\
3.22)\end{array}$ & $\begin{array}{l}(-26.44 \text { to } \\
-17.81)\end{array}$ & $(-24.80$ to -6.45$)$ & $\begin{array}{l}(-19.27 \text { to } \\
6.13)\end{array}$ & $\begin{array}{l}(-30.01 \text { to } \\
-17.76)\end{array}$ & $(-30.00$ to -4.63$)$ & \\
\hline \multirow{2}{*}{$\begin{array}{l}\text { Max. heart rate, } \\
\text { /min }\end{array}$} & 5.29 & -41.56 & -46.84 & 5.92 & -23.31 & -29.23 & $<0.001$ \\
\hline & $\begin{array}{l}(-11.00 \text { to } \\
21.58)\end{array}$ & $\begin{array}{l}(-50.89 \text { to } \\
-32.22)\end{array}$ & $\begin{array}{l}(-65.26 \text { to } \\
-28.42)\end{array}$ & $\begin{array}{l}(-6.47 \text { to } \\
18.31)\end{array}$ & $\begin{array}{l}(-29.01 \text { to } \\
-17.61)\end{array}$ & $\begin{array}{l}(-41.18 \text { to } \\
-17.28)\end{array}$ & \\
\hline \multirow{2}{*}{$\begin{array}{l}\text { Min. heart rate, } \\
\text { /min }\end{array}$} & 1.10 & -3.44 & -4.54 & 4.76 & -4.03 & -8.79 & 0.09 \\
\hline & $\begin{array}{l}(-2.83 \text { to } \\
5.02)\end{array}$ & $\begin{array}{l}(-6.26 \text { to } \\
-0.63)\end{array}$ & $(-9.86$ to 0.78$)$ & $\begin{array}{l}(-3.50 \text { to } \\
13.03)\end{array}$ & $\begin{array}{l}(-10.55 \text { to } \\
2.50)\end{array}$ & $(-20.95$ to 3.37$)$ & \\
\hline \multicolumn{8}{|c|}{ a mean difference with corresponding $95 \%$ confidence intervals. } \\
\hline \multicolumn{8}{|c|}{$\begin{array}{l}\text { P value compares mean differences of biomarkers between AF recurrence and sinus rhythm patients and are calculated } \\
\text { using 2-sample t tests. }\end{array}$} \\
\hline
\end{tabular}

\section{Associations of change in biomarker levels with rhythm status after cardioversion}

Changes in significant biomarker levels (BMP10 and NT-proBNP) remained associated with rhythm status when logistic models were separately adjusted for significant changes in clinical measures (S4 Table). In models adjusted for age and sex, change in BMP10 was significantly associated with rhythm status at follow-up (standardized $\beta,-2.03 ; 95 \% \mathrm{Cl},-3.06$ to $-1.00 ; \mathrm{P}<0.001$ ), shown in Table 5. Results remained similar with additional adjustment for demographic characteristics, risk factors for AF and changes in clinical measures. Similarly, there was a strong association between change in NT-proBNP and rhythm status at follow-up after age and sex adjustment (standardized $\beta,-3.98 ; 95 \% \mathrm{Cl},-5.75$ to $-2.22 ; \mathrm{P}<0.001$ ) and this relationship remained significantly associated after additional multivariable adjustments. Change in total bilirubin was not significantly associated with rhythm status at follow-up after extensive multivariable adjustment, as shown in Table 5. 


\begin{tabular}{|c|c|c|c|c|c|c|c|c|c|}
\hline \multirow[b]{3}{*}{ Model } & \multicolumn{9}{|c|}{ Predictor } \\
\hline & \multicolumn{3}{|c|}{ Change in BMP10, ng/mL } & \multicolumn{3}{|c|}{ Change in NT-proBNP, pg/mL } & \multicolumn{3}{|c|}{$\begin{array}{l}\text { Change in total bilirubin, } \\
\text { umol/L }\end{array}$} \\
\hline & $\begin{array}{l}\beta(95 \% \\
\mathrm{Cl})\end{array}$ & $\begin{array}{l}\text { Standardized } \\
\beta(95 \% \mathrm{Cl})^{c}\end{array}$ & $\begin{array}{l}P \\
\text { value }\end{array}$ & $\begin{array}{l}\beta(95 \% \\
\mathrm{Cl})\end{array}$ & $\begin{array}{l}\text { Standardized } \\
\beta(95 \% \mathrm{Cl})\end{array}$ & $\begin{array}{l}P \\
\text { value }\end{array}$ & $\begin{array}{l}\beta \\
(95 \% \\
\text { Cl) }\end{array}$ & $\begin{array}{l}\text { Standardized } \\
\beta(95 \% \mathrm{Cl})\end{array}$ & $\begin{array}{l}\mathrm{P} \\
\text { value }\end{array}$ \\
\hline \multirow[t]{2}{*}{ Univariable } & -4.25 & -1.97 & $<0.001$ & -0.005 & -3.93 & $<0.001$ & -0.24 & -0.85 & 0.018 \\
\hline & $\begin{array}{l}(-6.40 \\
\text { to } \\
-2.10)\end{array}$ & $\begin{array}{l}(-2.96 \text { to } \\
-0.97)\end{array}$ & & $\begin{array}{l}(-0.007 \\
\text { to } \\
-0.003)\end{array}$ & $\begin{array}{l}(-5.63 \text { to } \\
-2.23)\end{array}$ & & $\begin{array}{l}(-0.43 \\
\text { to } \\
-0.04)\end{array}$ & $\begin{array}{l}(-1.56 \text { to } \\
-0.15)\end{array}$ & \\
\hline \multirow{2}{*}{$\begin{array}{l}\text { Adjusted for } \\
\text { age and sex }\end{array}$} & -4.39 & -2.03 & $<0.001$ & -0.005 & -3.98 & $<0.001$ & -0.26 & -0.95 & 0.014 \\
\hline & $\begin{array}{l}(-6.62 \\
\text { to } \\
-2.15)\end{array}$ & $\begin{array}{l}(-3.06 \text { to- } \\
1.00)\end{array}$ & & $\begin{array}{l}(-0.007 \\
\text { to } \\
-0.003)\end{array}$ & $\begin{array}{l}(-5.75 \text { to } \\
-2.22)\end{array}$ & & $\begin{array}{l}(-0.48 \\
\text { to } \\
-0.04)\end{array}$ & $\begin{array}{l}(-1.71 \text { to } \\
-0.20)\end{array}$ & \\
\hline \multirow{2}{*}{$\begin{array}{l}\text { Multivariable } \\
\text { model } 1^{a}\end{array}$} & -5.30 & -2.47 & $<0.001$ & -0.006 & -4.67 & $<0.001$ & -0.26 & -0.92 & 0.029 \\
\hline & $\begin{array}{l}(-8.08 \\
\text { to } \\
-2.53)\end{array}$ & $\begin{array}{l}(-3.76 \text { to } \\
-1.18)\end{array}$ & & $\begin{array}{l}(-0.009 \\
\text { to } \\
-0.003)\end{array}$ & $\begin{array}{l}(-6.90 \text { to } \\
-2.43)\end{array}$ & & $\begin{array}{l}(-0.49 \\
\text { to } \\
-0.03)\end{array}$ & $\begin{array}{l}(-1.74 \text { to } \\
-0.09)\end{array}$ & \\
\hline \multirow{2}{*}{$\begin{array}{l}\text { Multivariable } \\
\text { model } 2^{b}\end{array}$} & -8.08 & -3.85 & 0.003 & -0.01 & -5.84 & 0.009 & -0.36 & -1.32 & 0.08 \\
\hline & $\begin{array}{l}(-13.32 \\
\text { to } \\
-2.83)\end{array}$ & $\begin{array}{l}(-6.34 \text { to } \\
-1.35)\end{array}$ & & $\begin{array}{l}(-0.02 \\
\text { to } \\
-0.002)\end{array}$ & $\begin{array}{l}(-10.22 \text { to } \\
-1.47)\end{array}$ & & $\begin{array}{l}(-0.75 \\
\text { to } \\
0.04)\end{array}$ & $\begin{array}{l}(-2.77 \text { to } \\
0.13)\end{array}$ & \\
\hline \multicolumn{10}{|c|}{$\begin{array}{l}\text { Estimates were obtained from logistic regression models where rhythm status at follow-up was the dependent variable and } \\
\text { change of biomarker was the independent variable. All models were adjusted for biomarker levels at baseline. } \\
\text { a Adjusted for age (years), sex, BMI }\left(\mathrm{kg} / \mathrm{m}^{2}\right) \text {, smoking status (active, past, never), hypertension (yes vs no), heart failure (yes } \\
\text { vs no) }\end{array}$} \\
\hline \multicolumn{10}{|c|}{ b Multivariable model 1, plus change in clinical parameters (diastolic BP, average heart rate, max. heart rate). } \\
\hline
\end{tabular}

None of the patients who had a reduction of both BMP10 and NT-proBNP levels below the respective median had an AF recurrence during follow-up (S5 Table).

\section{Discussion}

In this prospective study of patients undergoing electrical cardioversion for persistent AF, patients who were in sinus rhythm after 30 days of follow-up had considerable reductions in BMP10 and NT-proBNP levels, whereas patients with AF recurrence had no significant change in these levels. The reductions of BMP10 and NT-proBNP remained significantly associated with rhythm status at follow-up after multivariable adjustment, suggesting that these biomarker changes may reflect the change in rhythm status itself, given that most other covariates and comorbidities remained unchanged during the short follow-up of 30 days.

Circulating blood biomarkers have the potential to provide insights into the pathogenesis of AF and enhance risk prediction. We looked at a large set of 21 biomarkers and BMP10 and natriuretic peptides (including NT-proBNP and total NT-proBNP) were among the most significant ones. BMP10 is a heart-restricted protein that plays a role in cardiomyocyte development and growth ${ }^{8}$. Genes encoding for BMP10 are strongly expressed in the atria ${ }^{9}$. The secretion of BMP10 is regulated by PITX2, a 
gene variant known to be associated with $A F^{7,10,11}$. Reduced expression of PITX2 results in both higher levels of BMP10 and higher risk for development of $\mathrm{AF}^{7}$. BMP10 mRNA is expressed at low to undetectable levels in left ventricular tissue ${ }^{7}$, and appears not to be affected by other cardiovascular conditions that associate with AF such as heart failure ${ }^{12}$. Based on these findings, elevated levels of circulating BMP10 may reflect conditions that specifically affect the atria such as atrial fibrosis or increased myocardial contractions, both occurring in AF. In our study, BMP10 levels did not differ between groups prior to cardioversion (Table 2), but only when one group achieved stable sinus rhythm at 30 days. Patients who remained in AF had persistent increased BMP10 levels, and only those who converted into a stable sinus rhythm had significant reductions in BMP10 levels. To our knowledge, our study is the first to show that BMP10 may be directly linked to the actual heart rhythm. In future work, it would be interesting to investigate whether BMP10 alone or in addition to well known risk factors for AF has the potential to improve AF screening.

Natriuretic peptides including BNP and NT-proBNP have been well described as biomarkers associated with AF ${ }^{4,13-15}$. However, there are differences in analytical characteristics, pathophysiological interpretations, and clinical relevance between the measurement of BNP and NT-proBNP ${ }^{16}$. It has been shown that the ratio of NT-proBNP/BNP is not a constant value but varies according to various diseases and conditions ${ }^{17}$. Also, a great part of the differences between the various BNP immunoassays seems to be influenced by the cross-reaction with the glycosylated or not glycosylated proBNP ${ }^{18}$. In the absence of heart failure, it has been demonstrated that NT-proBNP is released primarily by the atria because of the increased myocardial contraction, volume load and wall stress caused by $\mathrm{AF}^{19}$. In previous studies including an analysis from this dataset, restoration of sinus rhythm through cardioversion led to a decrease in natriuretic peptides concentrations ${ }^{20-22}$. Our data extend these previous reports by demonstrating within-person reductions in NT-proBNP during a short-term follow-up in patients who were in sinus rhythm, and persistently elevated levels in those who remained in AF. This biomarker reduction was independently associated with sinus rhythm at follow-up, even after adjusting for clinical variable changes, suggesting that changes in NTproBNP are at least in part related to the heart rhythm.

Taken together, this is the first study to show that both BMP10 and NT-proBNP seem strongly dependent on the actual heart rhythm, which raises the issue of using these biomarkers to identify patients with undiagnosed AF. Although opportunistic screening for AF either by ECG monitoring or pulse taking in patients older than 65 years is recommended in guidelines ${ }^{23}$, studies indicate that such a screening strategy alone may not increase the detection rate of $A F^{24,25}$. Incorporating biomarkers into established screening strategies may therefore improve AF detection rates ${ }^{26,27}$. A prospective cohort study found that a NT-proBNP-stratified systematic screening for AF identifies more AF cases in high-risk individuals ${ }^{28}$. Our data provide evidence that not only NT-proBNP but also BMP10 are dependent on rhythm status suggesting that both biomarkers may be useful to detect AF. Future studies should assess whether biomarker testing using BMP10 and NT-proBNP has the potential to enhance identification of patients with undiagnosed AF.

We observed a significant reduction in total bilirubin in patients who were in sinus rhythm after cardioversion. However, this reduction did not remain statistically significant in multivariable analyses. Total bilirubin may therefore reflect an increased central venous pressure and mild liver congestion occurring in AF, rather than a direct effect of AF itself. Nevertheless, increased oxidative stress occurring during AF may further explain this association ${ }^{29}$, given the antioxidant properties of bilirubin ${ }^{30,31}$.

Although no significant difference in hs-TnT levels was found in patients who were in sinus rhythm after cardioversion compared to those who had AF recurrence, we observed elevated hs-TnT levels above the 99th percentile of the upper reference limit (>14 pg/mL) in 28 patients at both baseline and follow-up (S6 Table), suggesting that a significant proportion of these patients have some form of myocardial damage and/or increased troponin leakage. Prior studies have reported elevated hs$\mathrm{TnT}$ levels in patients with $\mathrm{AF}^{32-34}$. The underlying mechanisms are probably multifactorial and may include myocardial distress and increased oxygen demand (i.e. due to increased or irregular heart rates), myocardial dysfunction caused by variations in atrial and ventricular volume and pressure load, and the presence of comorbidities associated with myocardial damage such as heart failure and history of myocardial infarction. Given the high correspondence of elevated hs-TnT levels in our study, it is very likely that these values reflect chronic elevations and are not related to the rhythm status. 
The key strength of this prospective study is that we used a quasi-experimental setting to assess changes in a large number of conventional and new biomarker levels during $\mathrm{AF}$ and in sinus rhythm after cardioversion. However, there are potential limitations that deserve discussion. First, some patients with AF recurrence refused to attend the follow-up visit and follow-up blood samples were unavailable in these patients. Second, we included only patients with persistent AF undergoing electrical cardioversion, and the generalizability to other AF populations remains unclear. Third, we did not include transthoracic echocardiographic imaging measures in the analyses because of 1) missing data and 2) of suboptimal visualization of the atrial and ventricular cavities due to the irregular contraction in $\mathrm{AF}^{35}$. The reproducibility of systolic indices is also limited in patients with AF for the same reasons. Also, echocardiography is not widely available and adds complexity to any model trying to predict rhythm status. Finally, adjusting for echocardiographic variables may over-adjust the observed relationships by adjusting for variables in the causal pathway. Forth, follow-up screening for AF did not include continuous rhythm monitoring. It is possible that some intermittent AF recurrences may have been missed. However, all patients had a 24-hour ECG recording to document the actual rhythm status immediately prior to the follow-up visit where follow-up blood samples were drawn. Actual rhythm status was therefore known in all patients for 24 hours, such that it is highly unlikely that missed AF episodes prior to that had a substantial effect on the observed biomarker levels, and thereby on the relationship between the change in biomarker level and rhythm status. Finally, given that our study was hypothesis-generating, future studies are needed to validate our findings in other larger cohorts of patients without diagnosed AF.

In this prospective study, significant reductions of BMP10 und NT-proBNP levels were observed in patients who converted to sinus rhythm after cardioversion, but not in those with AF recurrence. Our analyses showed that even after multivariable adjustments, the results remained consistent, suggesting that these markers may be related, at least in part, to rhythm status in AF. The role of BMP10 in the identification of patients with undiagnosed AF should be examined in future studies.

\section{Methods}

\section{Study design and population}

Patients $\geq 18$ years old and scheduled for elective electrical cardioversion because of persistent AF were eligible for this study. They had to be on appropriate oral anticoagulation for at least 3 weeks prior to cardioversion. Exclusion criteria were acute heart failure, severe valvular disease, life-limiting active or chronic major diseases, and a history of cardiac surgery within 3 months prior to enrollment. Of the 128 patients enrolled into the study (enrollment period from March, 2010 to April, 2013 ), 28 were excluded from the analysis (S1 Fig). The main reason was that patients did not attend the follow-up visit ( $n=24)$. An additional 4 patients had missing information on biomarker levels at baseline, thus leaving a total of 100 patient for the present analysis. The study was conducted in accordance with the Declaration of Helsinki and was approved by the local ethics committee, Ethikkommission Nordwest- und Zentralschweiz (EKNZ). Written informed consent was obtained from all participants.

\section{Baseline study procedures}

After providing informed consent, all patients had a 24-hour Holter electrocardiogram (ECG) prior to the cardioversion to confirm the presence of persistent AF, and to document the heart rate profile. Baseline characteristics and comorbidities were collected using standardized case report forms. Three consecutive blood pressure measurements were obtained, and the mean of them was used in all analyses. Immediately before cardioversion, non-fasting venous blood samples were drawn for biomarker analyses. Electrical cardioversion was performed according to institutional guidelines.

\section{Follow-up and outcome}

For all patients, a follow-up visit was scheduled 30 days after cardioversion. Patients were advised to obtain an ECG every time they experience palpitations or other symptoms of potential AF recurrence. Immediately before the follow-up visit, all patients had another 24-hour ECG recording to document the prevalent rhythm. During the visit, three consecutive blood pressure measurements were obtained, and follow-up blood samples were drawn. Recurrence of AF was defined as any AF episode

Page 13/19 
lasting longer than 30 seconds on 24 -hour ECG monitoring ${ }^{36}$, or any ECG recording showing AF obtained during the follow-up period.

\section{Biomarker testing}

Immediately after the blood draw, plasma samples were centrifuged, aliquoted and stored at $-80^{\circ} \mathrm{C}$ in a central biobank. Biomarker levels were analyzed by personnel blinded to rhythm status. Levels of BMP10 were measured from EDTA plasma using a research grade prototype assay on a Cobas Elecsys e601 platform (Roche Diagnostics GmbH, Mannheim) employing Elecsys electrochemiluminescence technology. N-terminal pro-B-type natriuretic peptide (NT-proBNP) and total NT-proBNP levels were measured using a commercial sandwich immunoassay (NT-proBNP II, Roche Diagnostics GmbH, Mannheim) and a research grade prototype assay on the Elecsys e601 platform. NT-proBNP is a target for O-linked glycosylation of several serine and threonine residues ${ }^{18,37}$. Clinical data showed that glycosylation differences play a key role in the processing of proBNP in ventricular myocytes, and in its subsequent secretion ${ }^{38}$. For example, glycosylation at Thr48 and Thr71 inhibited proBNP processing and secretion from ventricular myocytes. In contrast, the glycosylation at other sites (e.g. Serine 44) appeared to increase the proBNP secretion from the myocytes. Because the corresponding glycosylating enzymes are influenced by various cardiac diseases, it has been postulated that the information on glycosylation might be clinically relevant for diagnosis and prognosis of heart disease ${ }^{38}$. For example, in acute heart failure, the proBNP glycosylation decreases (and furin activity increases), which synergistically amplifies the processing of proBNP into BNP and NT-proBNP ${ }^{39}$. For detection of NT-proBNP, the binding region of one sandwich monoclonal antibody is target of O-glycosylation at Serine 44 . The detection method of total NT-proBNP instead, is not influenced by Serine 44 O-linked glycosylation based on selection of the antibody-binding region further distant from this glycosylation site. Detailed technical assessment of NT-proBNP II ECLIA assay performance characteristics has been described previously ${ }^{40}$. Other biomarkers that were measured included: Fatty acid-binding protein 3 , endothelial cell-specific molecule 1, dickkopf-related protein 3, insulin-like growth factor-binding protein 7, myosin-binding protein C 3, high-sensitivity cardiac troponin T. More details on these biomarkers are provided in the Supplement. In addition, a number of laboratory measures were obtained from fresh blood samples that were immediately analyzed in the same hospital laboratory at baseline and during follow-up.

\section{Statistical analysis}

Continuous variables are presented as mean \pm standard deviation (SD) or median (interquartile range, [IQR]), as appropriate. Categorical data are presented as number (percentage). The distribution of continuous variables was checked using kurtosis and skewness, and by visual inspection of the histogram. Baseline variables were stratified by rhythm status at follow-up and compared using Wilcoxon rank-sum tests or Fisher's exact tests, as appropriate. Changes from baseline to follow-up in biomarker levels and clinical measures were compared between patients with and without AF recurrence during follow-up. Because change values did not show a skewed distribution, we used 2-sample t-tests to compare changes in biomarkers and clinical measures. Variables were retained for further analysis if the $p$ for difference reached the predefined threshold of $<0.01$. Correlations between significant biomarkers were evaluated at baseline and follow-up using Spearman's correlation coefficients and combined scatter and linear prediction plots were used to quantify these correlations. Differences between patients with and without AF recurrence were further investigated using logistic regression models with rhythm status as the dependent variable and change in biomarker levels or clinical variables as the independent variable. Separate models were fitted for each individual variable reaching the predefined significance threshold of 0.01. Baseline biomarker value was included as a covariate in each model. In order to compare coefficients between biomarkers, we calculated $\beta$ coefficients per change in 1 standard deviation (SD). Multivariable models were then adjusted for age, sex, smoking status, hypertension, heart failure (model 1), and model 1 plus significant changes in clinical measures (model 2). To evaluate whether the association between changes in the most significant biomarkers and rhythm status provides incremental information, we created 4 mutually exclusive groups, according to whether the change of biomarker levels was below or above the respective median of biomarker change and multivariable adjusted models were used to compare groups.

All statistical analyses were performed using STATA, version 17.0 (StataCorp LLC). Data analysis was performed from September 8, 2020, to November 20, 2020 and no additional patients were included between the end of the enrollment period

Page 14/19 
and statistical analyses.

\section{Abbreviations}

AF Atrial fibrillation

BMP10 Bone morphogenetic protein 10

BNP Brain natriuretic peptide

ECG Electrocardiogram

GAPP-AF Gene Expression Patterns for the Prediction of Atrial Fibrillation

mRNA Messenger ribonucleic acid

NT-proBNP N-terminal pro-B-type natriuretic peptide

\section{Declarations}

\section{Funding}

The GAPP-AF study was supported by a grant of the Mach Gaensslen Foundation. Dr. Conen and Dr. Kaufmann have received grants from the Swiss National Science Foundation (PP00P3_133681 and PP00P3_159322 to David Conen, 3232B0_141603 and 310030_149718 to Beat Kaufmann). Dr. Conen holds a McMaster University Department of Medicine Mid-Career Research Award. Dr. Kastner is an employee from Roche Diagnostics $\mathrm{GmbH}$ and performed the biomarker analyses. Roche Diagnostics $\mathrm{GmbH}$ provided support in the form of salaries, but did not have any additional role in the study design, data collection and analysis, decision to publish, or preparation of the manuscript. The specific roles of these authors are articulated in the 'author contributions' section.

\section{Author contributions}

Conceptualization: PBM, DC

Data curation: PBM, SA, PMK, GV, DC

Formal analysis: PBM

Funding acquisition: BAK, MK, SO, DC

Methodology: PBM, SA, SO, DC

Supervision: DC

Writing - original draft: PBM, DC

Writing - review \& editing: PBM, SA, SB, GV, PMK, EH, BAK, MK, SO, DC

\section{Competing interests statement}

Dr. Kühne reports personal fees from Bayer, personal fees from Böhringer Ingelheim, personal fees from Pfizer BMS, personal fees from Daiichi Sankyo, personal fees from Medtronic, personal fees from Biotronik, personal fees from Boston Scientific, personal fees from Johnson\&Johnson, grants from Bayer, grants from Pfizer, grants from Boston Scientific, grants from BMS, grants from Biotronik. Grants from the Swiss National Science Foundation (Grant numbers 33CS30_148474, 33CS30_177520, 32473B_176178), the Swiss Heart Foundation, the Foundation for Cardiovascular Research Basel and the University of Basel. 
Dr. Conen has received consultant/speaker fees from Roche Diagnostics; and BMS/Pfizer, both outside of the current work, Canada outside of the current work. The remaining authors have nothing to disclose.

\section{References}

1. Conen, D. et al. A multimarker approach to assess the influence of inflammation on the incidence of atrial fibrillation in women. European heart journal, 31, 1730-1736 https://doi.org/doi:10.1093/eurheartj/ehq146 (2010).

2. Rienstra, M. et al. Relation between soluble ST2, growth differentiation factor-15, and high-sensitivity troponin I and incident atrial fibrillation. American heart journal, 167, 109-115102 https://doi.org/doi:10.1016/j.ahj.2013.10.003 (2014).

3. Chua, W. et al. Data-driven discovery and validation of circulating blood-based biomarkers associated with prevalent atrial fibrillation. European heart journal, 40, 1268-1276 https://doi.org/doi:10.1093/eurheartj/ehy815 (2019).

4. Schnabel, R. B. et al. Relations of biomarkers of distinct pathophysiological pathways and atrial fibrillation incidence in the community., 121, 200-207 https://doi.org/doi:10.1161/circulationaha.109.882241 (2010).

5. Ellinor, P. T., Low, A. F., Patton, K. K., Shea, M. A. \& Macrae, C. A. Discordant atrial natriuretic peptide and brain natriuretic peptide levels in lone atrial fibrillation. Journal of the American College of Cardiology, 45, 82-86 https://doi.org/doi:10.1016/j.jacc.2004.09.045 (2005).

6. Staerk, L. et al. Protein Biomarkers and Risk of Atrial Fibrillation: The FHS. Circ Arrhythm Electrophysiol, 13, e007607 https://doi.org/doi:10.1161/circep.119.007607 (2020).

7. Reyat, J. S. et al. Reduced left atrial cardiomyocyte PITX2 and elevated circulating BMP10 predict atrial fibrillation after ablation. JCl Insight, 5, https://doi.org/doi:10.1172/jci.insight.139179 (2020).

8. Chen, H. et al. BMP10 is essential for maintaining cardiac growth during murine cardiogenesis. Development, 131, 2219$2231 \mathrm{https}: / /$ doi.org/doi:10.1242/dev.01094 (2004).

9. Hsu, J. et al. Whole genome expression differences in human left and right atria ascertained by RNA sequencing. Circ Cardiovasc Genet, 5, 327-335 https://doi.org/doi:10.1161/circgenetics.111.961631 (2012).

10. Gudbjartsson, D. F. et al. Variants conferring risk of atrial fibrillation on chromosome 4q25., 448, 353-357 https://doi.org/doi:10.1038/nature06007 (2007).

11. Roselli, C. et al. Multi-ethnic genome-wide association study for atrial fibrillation. Nat Genet, 50, 1225-1233 https://doi.org/doi:10.1038/s41588-018-0133-9 (2018).

12. Hodgson, J. et al. Characterization of GDF2 Mutations and Levels of BMP9 and BMP10 in Pulmonary Arterial Hypertension. Am J Respir Crit Care Med, 201, 575-585 https://doi.org/doi:10.1164/rccm.201906-11410C (2020).

13. Fan, J. et al. NT-proBNP, but not ANP and C-reactive protein, is predictive of paroxysmal atrial fibrillation in patients undergoing pulmonary vein isolation. J Interv Card Electrophysiol, 33, 93-100 https://doi.org/doi:10.1007/s10840-0119606-9 (2012).

14. Rienstra, M., Van Gelder, I. C., Van den Berg, M. P., Boomsma, F. \& Van Veldhuisen, D. J. Natriuretic peptides in patients with atrial fibrillation and advanced chronic heart failure: determinants and prognostic value of (NT-)ANP and (NT-pro)BNP. Europace, 8, 482-487 https://doi.org/doi:10.1093/europace/eul060 (2006).

15. Beck-da-Silva, L., de Bold, A., Fraser, M., Williams, K. \& Haddad, H. Brain natriuretic peptide predicts successful cardioversion in patients with atrial fibrillation and maintenance of sinus rhythm. Can J Cardiol, 20, 1245-1248 (2004).

16. Franzini, M. et al. Systematic differences between BNP immunoassays: comparison of methods using standard protocols and quality control materials. Clin Chim Acta, 424, 287-291 https://doi.org/doi:10.1016/j.cca.2013.07.001 (2013).

17. Rørth, R. et al. Comparison of BNP and NT-proBNP in Patients With Heart Failure and Reduced Ejection Fraction. Circ Heart Fail, 13, e006541 https://doi.org/doi:10.1161/circheartfailure.119.006541 (2020).

18. Clerico, A., Passino, C., Franzini, M. \& Emdin, M. Cardiac biomarker testing in the clinical laboratory: where do we stand? General overview of the methodology with special emphasis on natriuretic peptides. Clin Chim Acta, 443, 17-24 https://doi.org/doi:10.1016/j.cca.2014.06.003 (2015).

Page 16/19 
19. Casaclang-Verzosa, G., Gersh, B. J. \& Tsang, T. S. Structural and functional remodeling of the left atrium: clinical and therapeutic implications for atrial fibrillation. Journal of the American College of Cardiology, 51, 1-11 https://doi.org/doi:10.1016/j.jacc.2007.09.026 (2008).

20. Zografos, T., Maniotis, C., Katsivas, A. \& Katritsis, D. Relationship between brain natriuretic peptides and recurrence of atrial fibrillation after successful direct current cardioversion: a meta-analysis. Pacing Clin Electrophysiol, 37, 1530-1537 https://doi.org/doi:10.1111/pace.12477 (2014).

21. Kallergis, E. M. et al. Effect of sinus rhythm restoration after electrical cardioversion on apelin and brain natriuretic Peptide prohormone levels in patients with persistent atrial fibrillation. The American journal of cardiology, 105, 90-94 https://doi.org/doi:10.1016/j.amjcard.2009.08.656 (2010).

22. Raman, K. et al. Whole Blood Gene Expression Differentiates between Atrial Fibrillation and Sinus Rhythm after Cardioversion. PLoS One, 11, e0157550 https://doi.org/doi:10.1371/journal.pone.0157550 (2016).

23. Hindricks, G. et al. 2020 ESC Guidelines for the diagnosis and management of atrial fibrillation developed in collaboration with the European Association of Cardio-Thoracic Surgery (EACTS). European heart journal, doi:10.1093/eurheartj/ehaa612 (2020)

24. Uittenbogaart, S. B. et al. Opportunistic screening versus usual care for detection of atrial fibrillation in primary care: cluster randomised controlled trial., 370, m3208 https://doi.org/doi:10.1136/bmj.m3208 (2020).

25. Kaasenbrood, F. et al. Opportunistic screening versus usual care for diagnosing atrial fibrillation in general practice: a cluster randomised controlled trial. Br J Gen Pract, 70, e427-e433 https://doi.org/doi:10.3399/bjgp20X708161 (2020).

26. Schnabel, R. B. et al. Multiple biomarkers and atrial fibrillation in the general population. PLoS One, 9, e112486 https://doi.org/doi:10.1371/journal.pone.0112486 (2014).

27. Sinner, M. F. et al. B-type natriuretic peptide and C-reactive protein in the prediction of atrial fibrillation risk: the CHARGE-AF Consortium of community-based cohort studies. Europace, 16, 1426-1433 https://doi.org/doi:10.1093/europace/euu175 (2014).

28. Engdahl, J. et al. Stepwise mass screening for atrial fibrillation using N-terminal pro b-type natriuretic peptide: the STROKESTOP II study design. Europace, 19, 297-302 https://doi.org/doi:10.1093/europace/euw319 (2017).

29. Mihm, M. J. et al. Impaired myofibrillar energetics and oxidative injury during human atrial fibrillation., 104, 174-180 https://doi.org/doi:10.1161/01.cir.104.2.174 (2001).

30. Ziberna, L., Martelanc, M., Franko, M. \& Passamonti, S. Bilirubin is an Endogenous Antioxidant in Human Vascular Endothelial Cells. Sci Rep, 6, 29240 https://doi.org/doi:10.1038/srep29240 (2016).

31. Jansen, T. et al. Conversion of biliverdin to bilirubin by biliverdin reductase contributes to endothelial cell protection by heme oxygenase-1-evidence for direct and indirect antioxidant actions of bilirubin. J Mol Cell Cardiol, 49, 186-195 https://doi.org/doi:10.1016/j.yjmcc.2010.04.011 (2010).

32. Hijazi, Z. et al. High-sensitivity troponin T and risk stratification in patients with atrial fibrillation during treatment with apixaban or warfarin. Journal of the American College of Cardiology, 63, 52-61 https://doi.org/doi:10.1016/j.jacc.2013.07.093 (2014).

33. Turer, A. T. et al. Myocardial ischemia induced by rapid atrial pacing causes troponin T release detectable by a highly sensitive assay: insights from a coronary sinus sampling study. Journal of the American College of Cardiology, 57, 23982405 https://doi.org/doi:10.1016/j.jacc.2010.11.066 (2011).

34. Ulimoen, S. R. et al. Improved rate control reduces cardiac troponin T levels in permanent atrial fibrillation. Clin Cardiol, 37, 422-427 https://doi.org/doi:10.1002/clc.22281 (2014).

35. Kotecha, D., Mohamed, M., Shantsila, E., Popescu, B. A. \& Steeds, R. P. Is echocardiography valid and reproducible in patients with atrial fibrillation? A systematic review. Europace, 19, 1427-1438

https://doi.org/doi:10.1093/europace/eux027 (2017).

36. Calkins, H. et al. 2017 HRS/EHRA/ECAS/APHRS/SOLAECE expert consensus statement on catheter and surgical ablation of atrial fibrillation. Heart Rhythm 14, e275-e444, doi:10.1016/j.hrthm.2017.05.012 (2017)

Page $17 / 19$ 
37. Halfinger, B. et al. Unraveling the Molecular Complexity of O-Glycosylated Endogenous (N-Terminal) pro-B-Type Natriuretic Peptide Forms in Blood Plasma of Patients with Severe Heart Failure. Clin Chem, 63, 359-368 https://doi.org/doi:10.1373/clinchem.2016.265397 (2017).

38. Kuwahara, K., Nakagawa, Y. \& Nishikimi, T. Cutting Edge of Brain Natriuretic Peptide (BNP) Researchã€€- The Diversity of BNP Immunoreactivity and Its Clinical Relevance. Circ J, 82, 2455-2461 https://doi.org/doi:10.1253/circj.CJ-18-0824 (2018).

39. Vodovar, N. et al. Post-translational modifications enhance NT-proBNP and BNP production in acute decompensated heart failure. European heart journal, 35, 3434-3441 https://doi.org/doi:10.1093/eurheartj/ehu314 (2014).

40. Prontera, C. et al. Comparison between analytical performances of polyclonal and monoclonal electrochemiluminescence immunoassays for NT-proBNP. Clin Chim Acta, 400, 70-73 https://doi.org/doi:10.1016/j.cca.2008.10.011 (2009).

\section{Figures}

\section{Figure 1}

Box plots of percent changes in biomarker levels by rhythm status after cardioversion. Y-axis represents mean percent change in biomarker level; horizontal bars are median values; boxes, 25th and 75th percentiles; error bars, interquartile ranges; and dots, outliers.
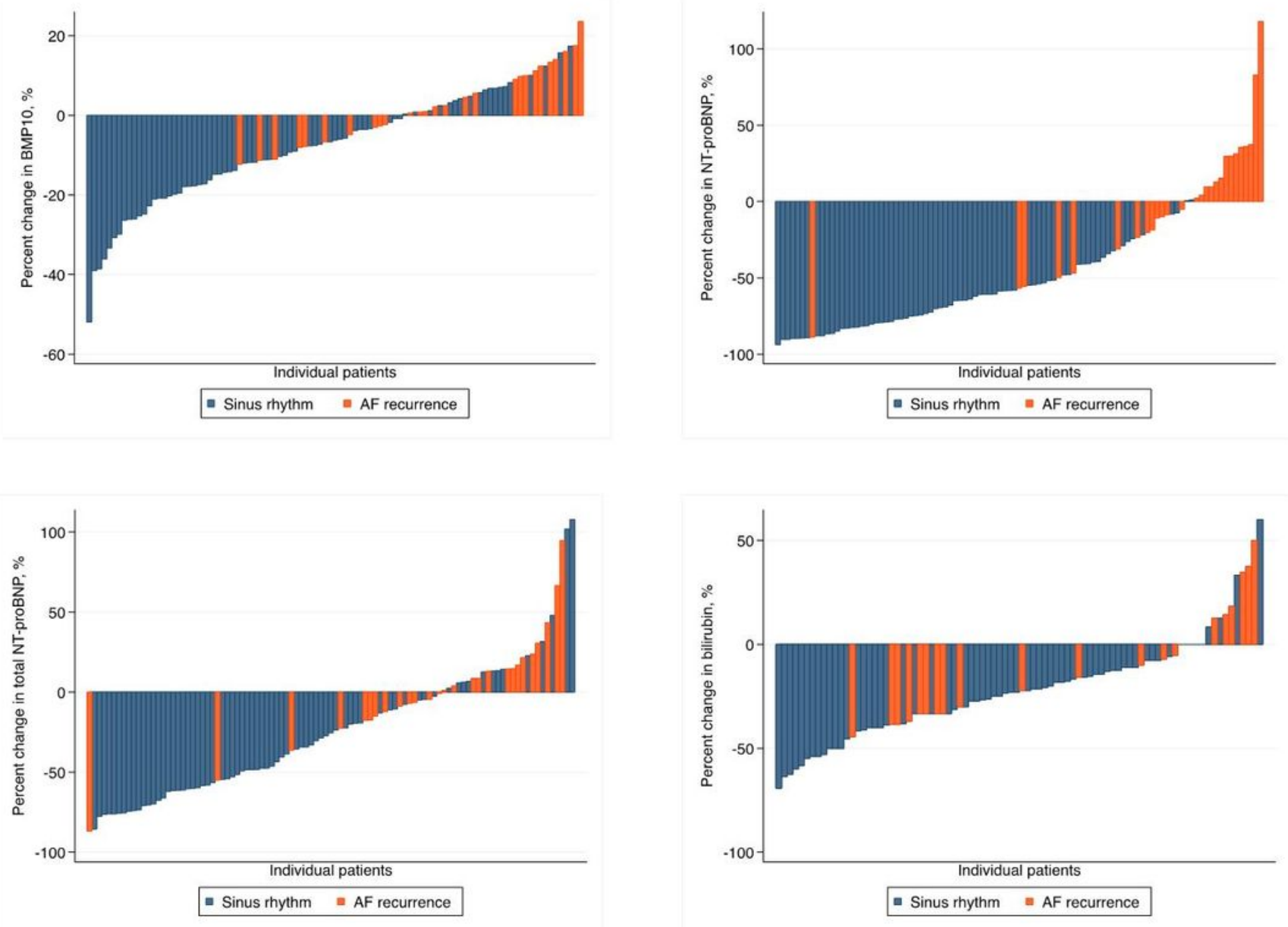

Figure 2 
Waterfall plots of percent changes in biomarker levels by rhythm status after cardioversion. X-axis represents individual patients, $y$-axis percentage change; bars are percent change of biomarker at follow-up for each patient.

\section{Supplementary Files}

This is a list of supplementary files associated with this preprint. Click to download.

- Supportinginformation.docx 